\title{
Impact of external nitrogen and phosphorus input between 2006 and 2010 on carbon cycle in China seas
}

\author{
Yang Gao $\cdot$ Nianpeng $\mathrm{He} \cdot$ Guirui Yu $\cdot$ \\ Jing Tian $\cdot$ Chiyuan Miao $\cdot$ Tiantian Yang
}

Received: 22 January 2013/ Accepted: 11 July 2014/Published online: 14 August 2014

(C) Springer-Verlag Berlin Heidelberg 2014

\begin{abstract}
It is widely accepted that excess nutrients change the dissolved inorganic carbon (DIC) system, which drives air-sea carbon dioxide $\left(\mathrm{CO}_{2}\right)$ exchanges, so the changes in the DIC system will then affect the oceans' carbon (C) biogeochemistry cycle. This study explores the impact of external nutrient input from 2006 to 2011 on the DIC system and air-sea $\mathrm{CO}_{2}$ exchanges in four largest coastal seas in China. The result demonstrates that external nutrient input significantly facilitates the biological uptake of DIC and promotes air-sea $\mathrm{CO}_{2}$ fluxes in coastal waters. The $\mathrm{C}$ sink caused by nitrogen $(\mathrm{N})$ and phosphorus (P) input for the Bohai Sea, the Yellow Sea, the East China Sea, and the South China Sea account for 46, 45, 11, and $59 \%$ of the total C sink, respectively. The excess nutrient input significantly changes the DIC system and C biogeochemistry cycle process in China Ocean. Up to a certain point, these effects are positive in increasing DIC levels and enhancing air-sea $\mathrm{CO}_{2}$ exchanges. However, the DIC levels may decrease if the nutrient increase is greater than
\end{abstract}

Editor: Jintao Xu.

Y. Gao $(\bowtie) \cdot$ N. He $\cdot$ G. Yu $\cdot$ J. Tian

Key Laboratory of Ecosystem Network Observation and

Modeling, Institute of Geographic Sciences and Natural

Resources Research, CAS, Beijing 100101,

People's Republic of China

e-mail: gaoyang@igsnrr.ac.cn

C. Miao $\cdot$ T. Yang

Department of Civil and Environmental Engineering,

University of California, Irvine, CA 92697, USA

\section{Miao}

State Key Laboratory of Earth Surface Processes and Resource Ecology, College of Global Change and Earth System Science, Beijing Normal University, Beijing 10085, People's Republic of China the capacity of the oceanic $\mathrm{C}$ system. In addition, the other impact factors, including sea level, winds, water, and air temperatures, and various human activities, such as agriculture, industry, and domestic discharge, also affect $\mathrm{N}$ and $\mathrm{P}$ transport, air-sea $\mathrm{CO}_{2}$ fluxes, and $\mathrm{C}$ biogeochemistry cycles.

Keywords Eutrophication - Air-sea $\mathrm{CO}_{2}$ exchange . Coastal $\cdot$ Nitrogen $\cdot$ Phosphorus $\cdot$ Dissolved inorganic carbon $\cdot$ Biogeochemistry

\section{Introduction}

Being the largest of the world's carbon (C) pools, oceanic ecosystems store an approximate $39,120 \mathrm{Pg}$ of inorganic $\mathrm{C}$ between surface water $(670-1,020 \mathrm{PgC})$ and the deep sea (36,730-38,100 PgC), including 1,000 Pg total organic C and $3 \mathrm{Pg}$ marine organism C (Siegenthaler and Sarmiento 1993; Falkowski et al. 2000). The oceans largely contribute to the $\mathrm{C}$ flux that takes place between oceanic ecosystems and the atmosphere. Of all carbon dioxide $\left(\mathrm{CO}_{2}\right)$ emitted into the atmosphere, one-quarter is absorbed by oceans, an approximate total of $2.3 \pm 0.4 \mathrm{PgC}$ of annual net $\mathrm{C}$ absorption, which is equivalent to the global net annual C uptake of terrestrial plant life (IPCC 2005; Global Carbon Project 2010). This is largely due to the structure of oceans, consisting of relatively simple producers, mostly in the form of short-lived, single-celled organisms. Photosynthetic organic products cannot fully be fixed after life cycle completion. Instead, the decomposition stage is rapidly entered, and the decomposition product is released back into the oceans and the atmosphere in the form of $\mathrm{CO}_{2}$ (Houghton 2007; Bouillon et al. 2008). 
One of the largest anthropogenic impact factors on oceanic $\mathrm{C}$ cycle is the discharge of nutrients (fertilizer, wastewater, etc.) into ocean waters, resulting in the eutrophication of coastal marine waters and the change of productivity and water acidity. As is well known, there are several biogeochemical processes leading to $\mathrm{C}$ sequestration in the ocean through photosynthesis. Eutrophication causes high water nutrient concentrations and lowers water transparency (Gao et al. 2012, 2014a), which favors some species and hurts others, distorting or disrupting coastal ecological ecosystem (Invers et al. 2004). Phytoplankton photosynthesis is the result of interplay between physical factors (irradiance and temperature) and phytoplankton nutrient and $\mathrm{C}$ storage and remobilization (Invers et al. 2002, 2004), so this process will fixes approximately $45 \mathrm{PgC} \mathrm{a}^{-1}$ (Falkowski et al. 2000). In addition, some of the particulate organic material formed by phytoplankton is deposited at the ocean floor and is thus sequestered (Raven and Falkowski 1999). As the increase of water acidity, the performance of algal growth potential is weakened, mainly because of acidification reducing phosphorus $(\mathrm{P})$ bioavailability, resulting in aquatic ecosystem being oligotrophic and the formation of sulfate deposition in the ocean (Larssen et al. 2011).

Owing to this, the interaction of the dissolved inorganic carbon (DIC) system with nutrient uptake of algae in sea water has aroused international concern (Gao et al. 2014b). Most aquatic plants photosynthesize by means of $\mathrm{CO}_{2}$, and only a few species use $\mathrm{HCO}_{3}{ }^{-}$(Raven and Falkowski 1999; Zhi et al. 2008). It is clear that phytoplankton growth is affected by the DIC levels as well as by the available nutrients. The availability of $\mathrm{HCO}_{3}{ }^{-}$and $\mathrm{CO}_{2}$ fluctuates since the composition of the DIC depends on the biological activity (Zhang et al. 2012). Huertas et al. (2000) have reported that the uptake of $\mathrm{NO}_{3}{ }^{-}$and $\mathrm{PO}_{4}{ }^{3-}$ by phytoplankton depended on the level of DIC. Excess anthropogenic nitrogen $(\mathrm{N})$ and $\mathrm{P}$ input change sea water chemistry, leading to sea water acidification and a reduction in total alkalinity, which in turn cause changes in DIC concentration (Doney et al. 2007). Hence, it is very important to estimate the impact of anthropogenic $\mathrm{N}$ and $\mathrm{P}$ input by measuring the changes in DIC. In addition, an increase in temperature or salinity would also decrease the solubility of $\mathrm{CO}_{2}$ (Bakker et al. 1999). DIC and total alkalinity are conservative parameters when the water in the top layers mixes with that in the lower layers; this mixing process helps determine sea water $\mathrm{pH}$ and the partial pressure of $\mathrm{CO}_{2}\left(\mathrm{pCO}_{2}\right)$ as well as temperature and salinity (Bakker et al. 1999; Zeebe and Wolf-Gladrow 2005). Higher values of $\mathrm{pCO}_{2}$ drive increased air-sea $\mathrm{CO}_{2}$ exchange (Frankignoulle et al. 1998).

The area of the China seas is vast and has a total area of $4.71 \times 10^{6} \mathrm{~km}^{2}$ (including $1.71 \times 10^{6} \mathrm{~km}^{2}$ of inland and offshore maritime expanse and a seazone comprising of a $3 \times 10^{6} \mathrm{~km}^{2}$ continental shelf), which accounts for $1.3 \%$ of the total area of the world's oceans, ranking fifth in nations. Several large Chinese river systems discharge freshwater, burdened with nutrients, into this larger marine area. This nutrient input is responsible for the increasing of water eutrophication and changing water quality and productivity. Moreover, the phytoplankton consumes large amounts of DIC, resulting in lower $\mathrm{pCO}_{2}$, and strengthens air-sea $\mathrm{CO}_{2}$ flux. This study investigates the impact of $\mathrm{N}$ and $\mathrm{P}$ input on the DIC system in China coastal ecosystem for the period of 2006-2011 and then estimates the contribution of external $\mathrm{N}$ and $\mathrm{P}$ input to $\mathrm{C}$ cycle in China seas.

\section{Methods}

\section{Study area}

The study area is bordered by the P. R. China coastline and includes four named seas (Fig. 1): the Bohai Sea, the Yellow Sea, the East China Sea, and the South China Sea. The Bohai Sea $\left(37^{\circ} 07^{\prime}-41^{\circ} 0^{\prime} \mathrm{N}, 117^{\circ} 35^{\prime}-121^{\circ} 10^{\prime} \mathrm{E}\right)$ is the only inland sea. It spans an area of $7.7 \times 10^{4} \mathrm{~km}^{2}$ and is bordered by $2,688 \mathrm{~km}$ of P. R. China coastline. The annual average temperature is $10{ }^{\circ} \mathrm{C}$; salinity is 30 ; and $\mathrm{pH}$ values range from 7.86 to 8.30 . The Yellow Sea $\left(35^{\circ}\right.$ $\left.45^{\circ} \mathrm{N}, 120^{\circ}-123^{\circ} \mathrm{E}\right)$ covers an area of $3.8 \times 10^{5} \mathrm{~km}^{2}$. The annual average temperature is $12{ }^{\circ} \mathrm{C}$; salinity is 32 or more; and $\mathrm{pH}$ values range from 7.9 to 8.10 . The East China Sea $\left(23^{\circ} 00^{\prime}-33^{\circ} 10^{\prime} \mathrm{N}, 117^{\circ} 11^{\prime}-131^{\circ} 00^{\prime} \mathrm{E}\right)$ spans an area of $7.52 \times 10^{5} \mathrm{~km}^{2}$. The annual average temperature is $20^{\circ} \mathrm{C}$; salinity is 33 ; and $\mathrm{pH}$ values range from 7.8 to 8.20 . The South China Sea $\left(3^{\circ} 40^{\prime}-11^{\circ} 50^{\prime} \mathrm{N}, 109^{\circ} 33^{\prime}-117^{\circ} 50^{\prime} \mathrm{E}\right)$ is an open sea covering an area of $3.5 \times 10^{6} \mathrm{~km}^{2}$. The annual average temperature is $25^{\circ} \mathrm{C}$; salinity is 32 ; and $\mathrm{pH}$ values range from 8.0 to 8.2 .

Relationship between nutrient input and DIC system

DIC in sea water consists of roughly $90 \%$ bicarbonate $\left(\mathrm{HCO}_{3}{ }^{-}\right), 9 \%$ carbonate $\left(\mathrm{CO}_{3}{ }^{2-}\right), 0.5-1 \% \mathrm{CO}_{2}$, and $0.002 \%$ carbonic acid $\left(\mathrm{H}_{2} \mathrm{CO}_{3}\right)$

$\mathrm{DIC}=\left[\mathrm{HCO}_{3}^{-}\right]+\left[\mathrm{CO}_{3}^{2-}\right]+\left[\mathrm{CO}_{2}\right]+\left[\mathrm{H}_{2} \mathrm{CO}_{3}\right]$.

Zhang et al. (2007) reported effect of external $\mathrm{N}$ and $\mathrm{P}$ addition on the sea water DIC system and the results of $\mathrm{N}$ and $\mathrm{P}$ inputs at a temperature of $15{ }^{\circ} \mathrm{C}$ over a range of $\mathrm{pH}$ values. The relationship between $\mathrm{N}$ and $\mathrm{P}$ input and DIC values was shown in Table 1 . Therefore, there would be a synergistic effect if different nutrients were added to the DIC system in combination. This synergistic effect was best expressed as a multiple regression: 


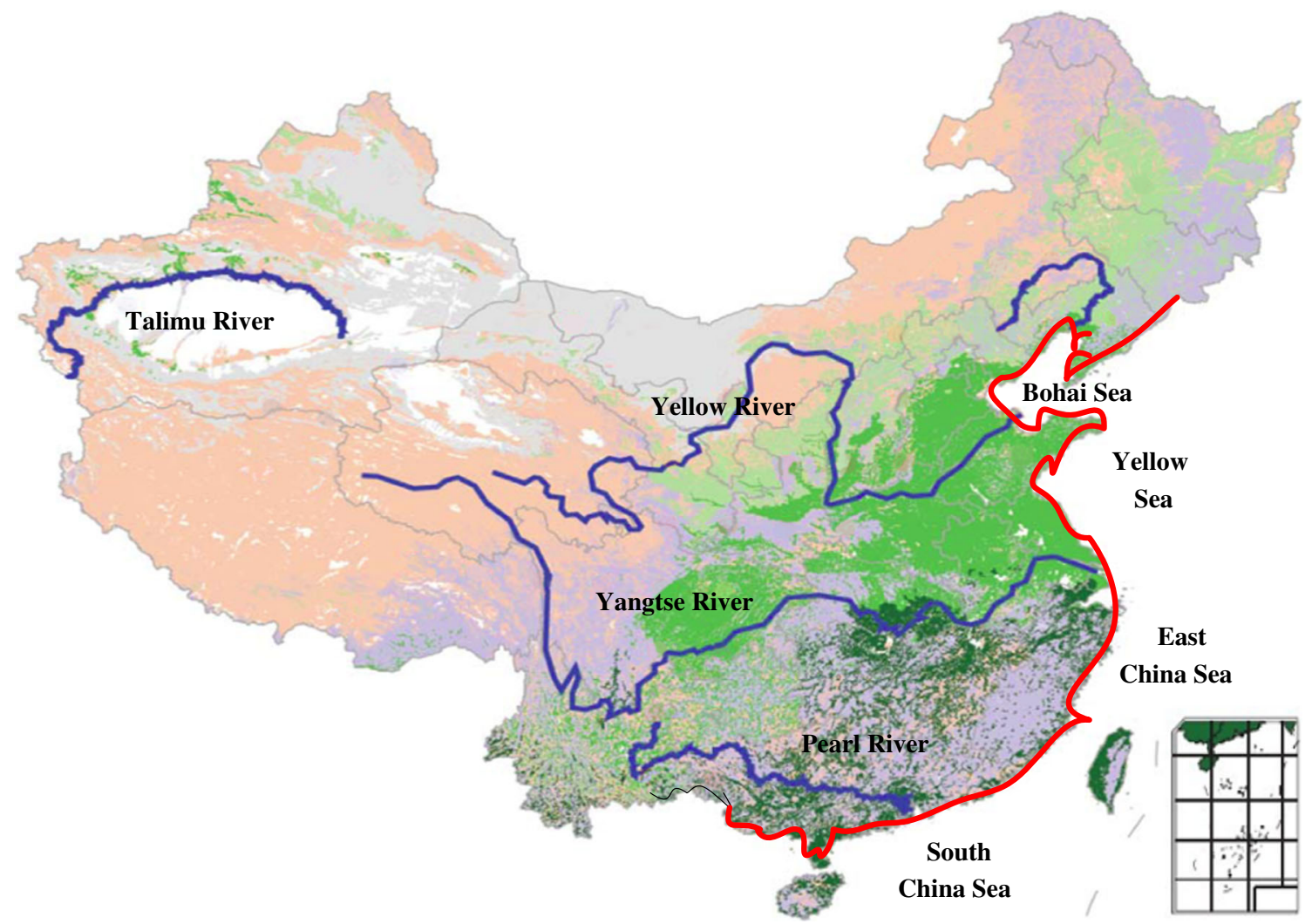

Fig. 1 The geographic location for the Bohai Sea, the Yellow Sea, the East China Sea, and the South China Sea, wherein red line is coastline and blue line is main river system in China (colour figure online)

Table 1 Correlation between nutrients and constituents of DIC system

\begin{tabular}{lllll}
\hline Nutrient & $\mathrm{DIC}$ & $\mathrm{HCO}_{3}{ }^{-}$ & $\mathrm{CO}_{3}{ }^{2-}$ & $\mathrm{pCO}_{2}$ \\
\hline $\mathrm{NO}_{3}{ }^{-}$ & $-0.502 * *$ & $-0.579 * *$ & $0.628^{* *}$ & $-0.713 * *$ \\
$\mathrm{NH}_{4}{ }^{+}$ & $-0.514 * *$ & $-0.644 *$ & $0.647 * *$ & $-0.675^{* *}$ \\
$\mathrm{NO}_{2}{ }^{-}$ & $-0.316^{*}$ & $\mathrm{~ns}$ & $0.323^{*}$ & $-0.394 *$ \\
$\mathrm{PO}_{4}{ }^{3-}$ & $-0.542 * *$ & $-0.592 * * *$ & $0.672 * *$ & $-0.766 * *$ \\
\hline
\end{tabular}

ns: $p>0.05 ; * p<0.05 ; * * p<0.01 ; * * * p<0.001$

$Y=a+b_{1} X_{1}+b_{2} X_{2}+\cdots+b_{k} X_{k}$

where $Y$ is a dependent variable; $a$ is a constant term; $b$ is a partial regression coefficient; and $X_{k}$ is an environmental factors variable, such as $\Delta \mathrm{NO}_{3}{ }^{-}, \Delta \mathrm{NH}_{4}{ }^{+}, \Delta \mathrm{NO}_{2}{ }^{-}$, and $\Delta \mathrm{PO}_{4}{ }^{3-}$.

The relationship between different forms of $\mathrm{N}$ and $\mathrm{P}$ input and DIC can be expressed by the partial regression:

$$
\begin{aligned}
\Delta \mathrm{DIC}= & -0.937\left(\Delta \mathrm{PO}_{4}^{3-}\right)-0.34\left(\Delta \mathrm{NO}_{3}^{-}\right) \\
& -0.46\left(\Delta \mathrm{NH}_{4}^{+}\right)+0.11\left(\Delta \mathrm{NO}_{2}^{-}\right) \\
& \left(R^{2}=0.69, n=30, p<0.05\right)
\end{aligned}
$$

$$
\begin{aligned}
\Delta \mathrm{pCO}_{2}= & -1.321\left(\Delta \mathrm{PO}_{4}^{3-}\right)-0.12\left(\Delta \mathrm{NO}_{3}^{-}\right) \\
& -0.31\left(\Delta \mathrm{NH}_{4}^{+}\right)-0.032\left(\Delta \mathrm{NO}_{2}^{-}\right) \\
& \left(R^{2}=0.85, n=35, p<0.01\right)
\end{aligned}
$$

where the units of $\Delta \mathrm{DIC}, \Delta \mathrm{NO}_{3}{ }^{-}, \Delta \mathrm{NH}_{4}{ }^{+}, \Delta \mathrm{NO}_{2}{ }^{-}$, and $\Delta \mathrm{PO}_{4}{ }^{3-}$ in Eqs. 3 and 4 are expressed in $\mu \mathrm{mol} \mathrm{L}^{-1}$; the unit of $\Delta \mathrm{pCO}_{2}$ is $\mu \mathrm{atm}$. Equations 3 and 4 imply that variations of DIC components show significantly correlation with nutrient input/concentration. The most pronounced relationship is the one between $\Delta \mathrm{pCO}_{2}$ and nutrient input. This may be due to the phytoplankton photosynthesis, and decomposition consumes the free state of $\mathrm{CO}_{2}$ in sea water.

Air-sea $\mathrm{CO}_{2}$ flux and sink calculations

The air-sea fluxes $(F)$ of $\mathrm{CO}_{2}$ are calculated according to the equation:

$F=k s\left(f \mathrm{CO}_{2}^{\text {water }}-f \mathrm{CO}_{2}^{\text {air }}\right)$

where $k$ is the gas transfer velocity in $\mathrm{cm} \mathrm{h}^{-1}$ (depending on wind speed and temperature), which is determined by the two methods (Eqs. 6, 7); $s$ is the solubility of $\mathrm{CO}_{2}$ in 
sea water in $\mu \mathrm{mol} \mathrm{m}{ }^{3} \mu \mathrm{atm}^{-1}$; $f \mathrm{CO}_{2}^{\text {water }}$ is the $\mathrm{CO}_{2}$ fugacity in the ocean in $\mu \mathrm{atm}$; $f \mathrm{CO}_{2}^{\text {air }}$ is the $\mathrm{CO}_{2}$ fugacity in the atmosphere in $\mu \mathrm{atm} ; f \mathrm{CO}_{2}^{\text {water }}-f \mathrm{CO}_{2}^{\text {air }}$ represent $\Delta \mathrm{pCO}_{2}$; $F$ is expressed in $\mu \mathrm{mol} \mathrm{CO}_{2} \mathrm{~m}^{-2} \mathrm{~d}^{-1}$

$k=0.17 \mathrm{U}_{10} \quad\left(\mathrm{U}_{10}<3.6 \mathrm{~m} \mathrm{~s}^{-1}\right)$

$k=2.85 \mathrm{U}_{10}-9.65 \quad\left(3.6 \mathrm{~m} \mathrm{~s}^{-1}<\mathrm{U}_{10}<13 \mathrm{~m} \mathrm{~s}^{-1}\right)$

$k=5.9 \mathrm{U}_{10}-49.3 \quad\left(\mathrm{U}_{10}>13 \mathrm{~m} \mathrm{~s}^{-1}\right)$

$k=0.39 \mathrm{U}_{10}^{2}(\mathrm{Sc} / 660)-1 / 2 \quad$ (long term average wind)

$k=0.31 \mathrm{U}_{10}^{2}(\mathrm{Sc} / 660)-1 / 2 \quad($ steady/short term wind $)$

where $\mathrm{U}_{10}$ is the mean wind speed at 10 -m distance to sea level; Sc is Schmidt constant; 660 is Schmidt constant (Liss and Merlivat 1986; Wanninkhof 1992).

Data analysis

Our analysis is based on the data from 204 water quality monitoring stations on the major river deltas in China and along the China coastline. Data are tracked and recorded by the China National Environmental Monitoring Center. Data on $\mathrm{N}$ and $\mathrm{P}$ discharge, concentration, and coastal water quality are taken from Chinese River and sediment Bulletin, Chinese Environment Bulletin, Chinese Oceanic quality Bulletin, and China Marine Environment Quality Bulletin, 2006-2011.

For the study years (2006-2011), the value of parameter $k$ was $10.3 \mathrm{~cm} \mathrm{~h}^{-1}$, which is the mean value for continental shelf off the China coast according to Tsunogai et al. (1999). The solubility of $\mathrm{CO}_{2}$ is computed monthly as a function of temperature and salinity according to Weiss (1974), by the following formula:

$$
\begin{aligned}
\operatorname{lns}= & A_{1}+A_{2}(100 / T)+A_{3} \ln (T / 100)+S \\
& \times\left[B_{1}+B_{2}(T / 100)+B_{3}(T / 100)^{2}\right]
\end{aligned}
$$

where $T$ is temperature in $K$; $S$ is salinity; $A_{1}=-58.0931$; $A_{2}=90.5096 ; \quad A_{3}=22.2940 ; \quad B_{1}=0.027766 ; \quad B_{2}=$ $-0.025888 ; B_{3}=0.0050578$.

\section{Results}

Nutrient discharge from 2006 to 2011

As Fig. 2 shows, the main nutrient input was nitrate, which constitutes of $80 \%$ of the nutrient discharged into Chinese coastal waters. From 2006 to 2011, the amount of nutrient discharged into Chinese waters increased, with the exception that there was a slight decrease in nitrate and ammonium salt discharge into the South China and East China seas. The East China Sea was subject to the most serious eutrophication of all the waters monitored with exceptionally high-nutrient inputs. As Fig. 1 shows, the Yangtse River flows into the East China Sea, and the Yangtse River delta is the most developed industrial area in China and generates a large volume of industrial wastewater. Although wastewater discharge is gradually decreasing due to that Environmental Protection Bureau strengthens the control on wastewater discharge from industry, the level of nutrient discharge is still very high.

However, as Fig. 3 shows, the changes in individual nutrient concentrations were independent of nutrient discharge amounts to some extent. For example, nitrate concentration in the South China Sea grew more quickly than that in other seas. The rate of nitrate concentration growth was also pronounced for the East China Sea, but ranked behind the rate for the South China Sea. The Yellow Sea showed the highest rate of growth in ammonium salt concentration. For all seas, the rates of nitrate concentration changes showed more fluctuations than that for any other nutrient changes, and the changes in phosphate concentration from 2006 to 2011 were the least pronounced. This was easily explained by the fact that nitrate was the main component of non-point source pollution and accounted for the largest proportion of the nutrient export caused by agricultural and industrial discharge.

\section{Changes in the DIC system}

According to Eq. (3), the relationship between DIC and nutrient discharge showed significant partial correlation and the external nutrient input would consume DIC and lead to changes in the sea water DIC system. As Fig. 4 shows, annual DIC consumption in the East China Sea (approximately $4 \mathrm{Tg}$ annually) was the highest and it was the lowest in the Bohai Sea. In addition, the changes in the DIC system, which were driven by nutrient input into the four seas, correlated with the changes in rates of nitrate discharge to a great extent.

Air-sea $\mathrm{CO}_{2}$ fluxes

As Table 2 shows, the changes in DIC concentration did not correlate with the measurements of air-sea $\mathrm{CO}_{2}$ flux. From 2006 to 2011, the greatest change in DIC concentration was shown in the Yellow Sea: minus $4.69 \mu \mathrm{mol} \mathrm{L}^{-1}$. External nutrient input into the body of water resulted in some $1.41 \mathrm{mmol} \mathrm{m}^{-2} \mathrm{~d}^{-1}$ of $\mathrm{CO}_{2}$ input. The rate of change in DIC was the smallest in the East China Sea compared to that in any other Chinese coastal waters. The mean air-sea $\mathrm{CO}_{2}$ flux in East China Sea was $4.89 \mathrm{gC} \mathrm{m}^{-2} \mathrm{a}^{-1}$, while the $\mathrm{CO}_{2}$ input into the East China Sea was estimated at $1.03 \mathrm{mmol} \mathrm{m}^{-2} \mathrm{~d}^{-1}$. The South 

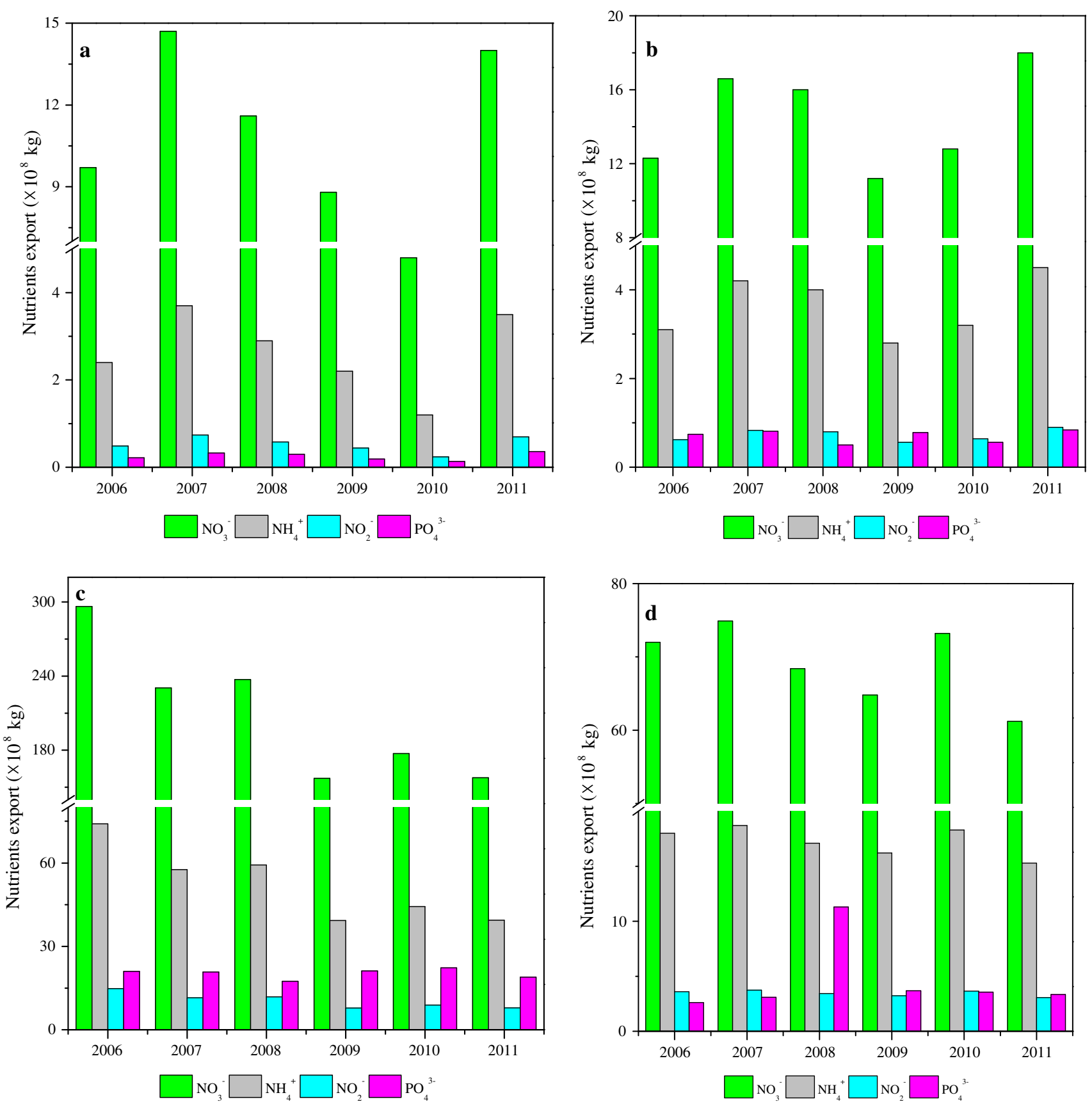

Fig. 2 Nutrients discharged into the Bohai Sea (a), the Yellow Sea (b), the East China Sea (c), and the South China Sea (d) from 2006 to 2011 (unit: $\times 10^{8} \mathrm{~kg}$ )

China Sea, as the largest seas in the PR China, had the lowest air-sea $\mathrm{CO}_{2}$ flux: minus $4.32 \mathrm{gC} \mathrm{m}^{-2} \mathrm{a}^{-1}$. The $\mathrm{CO}_{2}$ sink fluctuated over the whole years with the highest value of $15.1 \mathrm{Tg}$. This accounted for $69.68 \%$ of the total $\mathrm{CO}_{2}$ sink (Fig. 5). The East China Sea was the second largest $\mathrm{CO}_{2}$ sink in China Seas, amounting to $3.67 \mathrm{Tg}$ at its highest annual value. It constituted $16.94 \%$ of the total $\mathrm{CO}_{2}$ sink. The Bohai Sea contained the smallest percentage of the total $\mathrm{CO}_{2}$ sink.

\section{Discussion}

Impact of nutrients input on oceanic $\mathrm{C}$ sink for China

As Fig. 6 shows, the $\mathrm{C}$ flux of China seas exhibited great variations and large $\mathrm{C}$ sinks based on long-term monitoring. Oceans absorb atmospheric $\mathrm{CO}_{2}$ in an attempt to reach equilibrium through direct air-sea exchanges, but this process takes place at an extremely slow rate (Chen et al. 

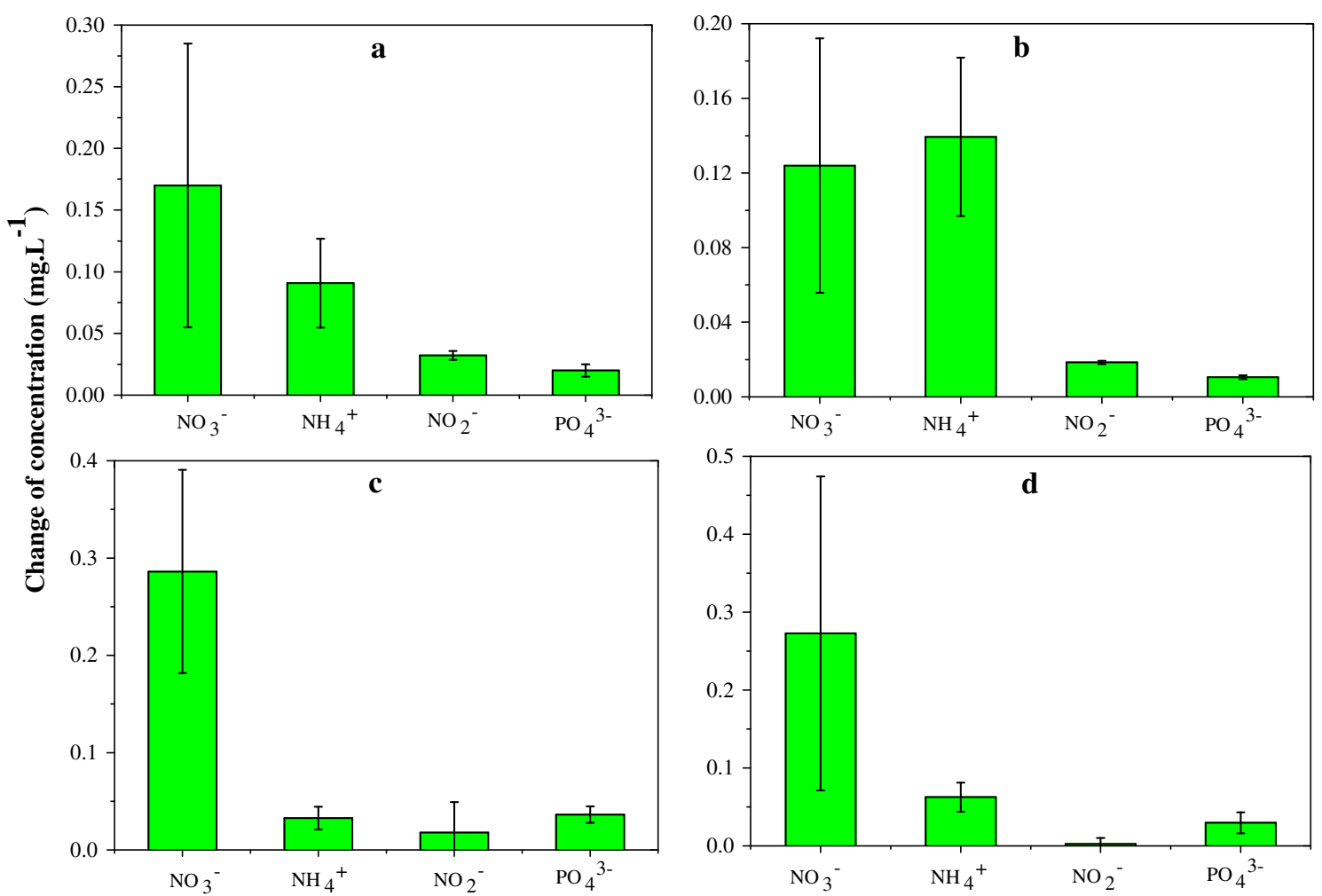

Fig. 3 Changes in nutrient concentrations in the Bohai Sea (a), the Yellow Sea (b), the East China Sea (c), and the South China Sea (d), 2006-2011

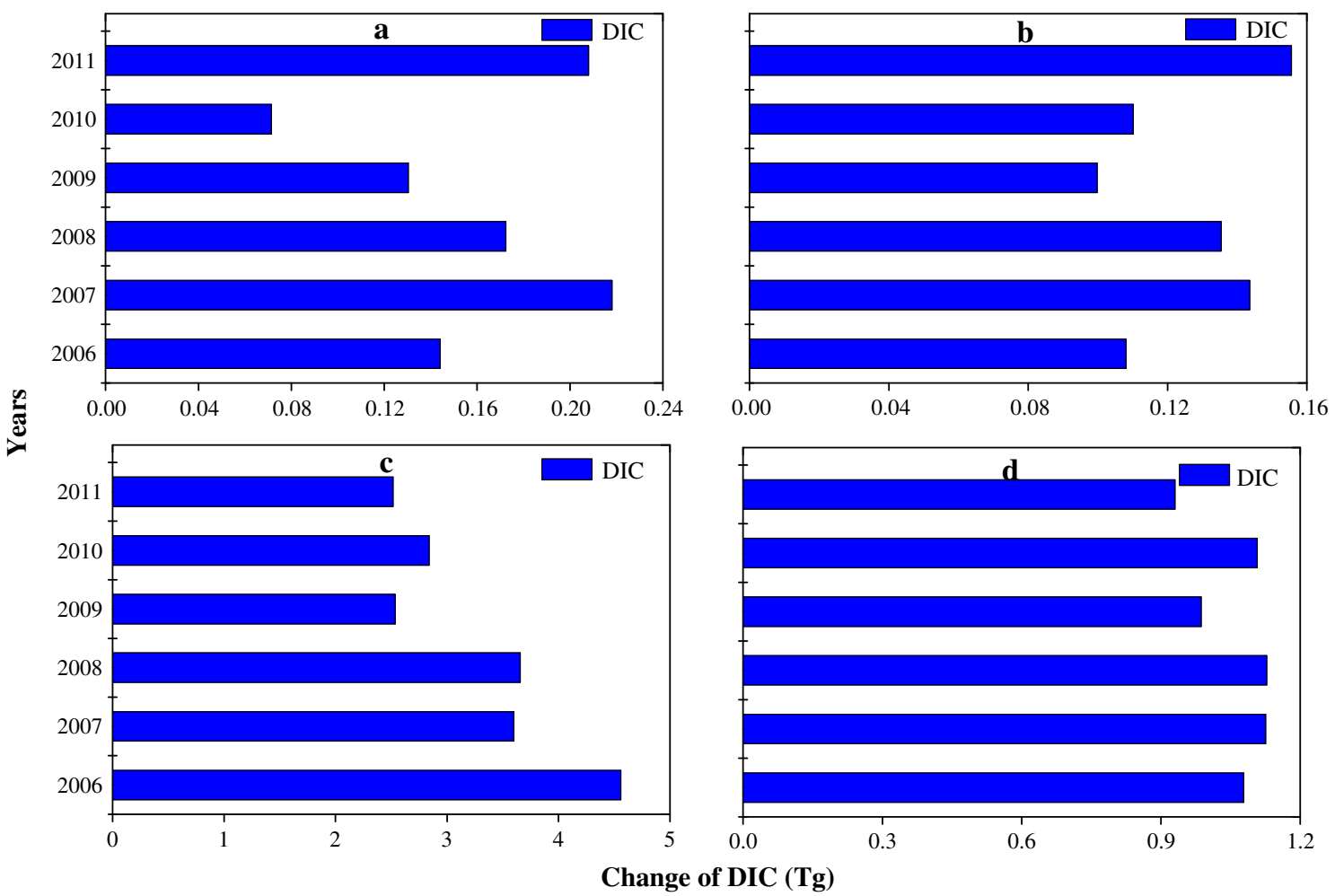

Fig. 4 Changes in DIC levels in the Bohai Sea (a), the Yellow Sea (b), the East China Sea (c), and the South China Sea (d), 2006-2011 
Table 2 Changes in DIC levels and $\mathrm{CO}_{2}$ flux in China coastal seas, 2006-2011

\begin{tabular}{llllll}
\hline Sea & Area $\left(\mathrm{km}^{2}\right)$ & $\begin{array}{l}\Delta \mathrm{DIC} \\
(\mu \mathrm{mol} \mathrm{L}\end{array}$ & $\begin{array}{l}\Delta \mathrm{pCO}_{2} \\
(\mu \mathrm{atm})\end{array}$ & $\begin{array}{l}\Delta F \\
\left(\mathrm{mmol} \mathrm{m}^{-2} \mathrm{~d}^{-1}\right)\end{array}$ & $\begin{array}{l}\text { Mean flux } \\
\left(\mathrm{gC} \mathrm{m}^{-2} \mathrm{a}^{-1}\right)\end{array}$ \\
\hline Bohai Sea & $7.7 \times 10^{4}$ & -3.48 & -2.27 & -0.98 & -4.65 \\
Yellow Sea & $3.8 \times 10^{5}$ & -4.69 & -3.24 & -1.41 & -6.69 \\
East China Sea & $7.5 \times 10^{5}$ & -3.31 & -2.38 & -1.03 & -4.89 \\
South China Sea & $3.5 \times 10^{6}$ & -3.47 & -2.08 & -0.91 & -4.32 \\
\hline
\end{tabular}

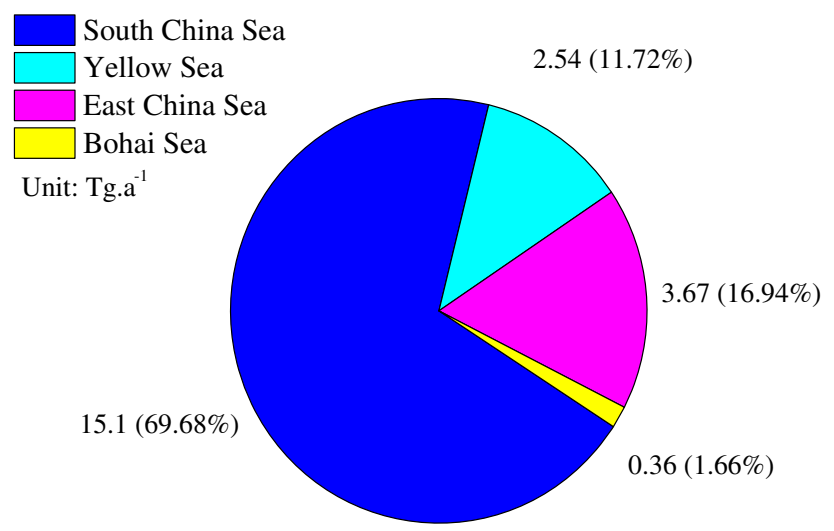

Fig. 5 Contribution of nutrient discharge to $\mathrm{CO}_{2}$ sinks in the China seas

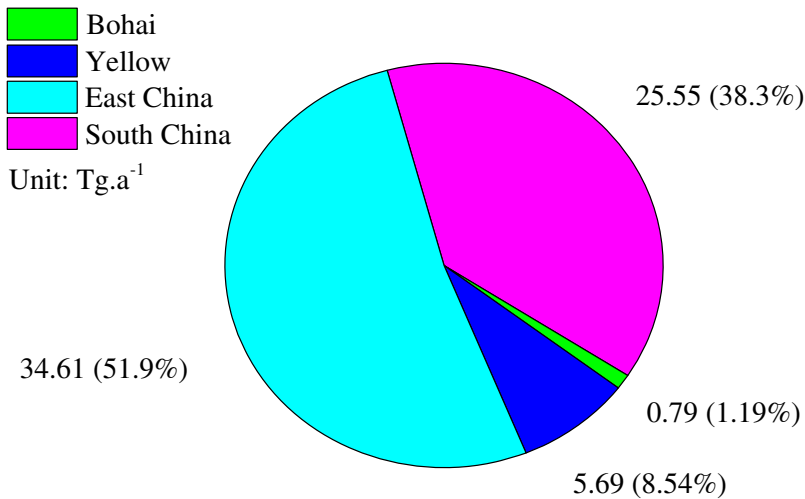

Fig. 6 The annual net $\mathrm{CO}_{2}$ uptake or release by the China seas

2003). China's marine ecosystems can absorb $65.06 \mathrm{TgC}$ from the atmosphere every year. Except the Bohai Sea showing annual net $\mathrm{CO}_{2}$ release, annual net $\mathrm{CO}_{2}$ uptakes from the Yellow Sea, the East China Sea, and the South China Sea were 5.69, 34.61, and $25.55 \mathrm{TgC}$, respectively, which were estimated according to Chinese Oceanic Quality Bulletin, 2006-2011 (Fig. 6), confirming their status as atmospheric $\mathrm{CO}_{2}$ sinks. Given that the annual global C sink of oceans is $2.0-2.2 \mathrm{PgC}$ (González et al. 2008), the China seas account for 3.0-3.3\% of the ocean net $\mathrm{C}$ sink globally. Compared to previous estimation (Table 3), the largest difference existed at East China Sea and South China Sea, which showed considerable annual changes. The difference could be largely attributed to the
Table 3 Estimation of $\mathrm{C}$ source/pool in the China seas

\begin{tabular}{lll}
\hline Name & $\mathrm{C} \operatorname{sink} /\left(\mathrm{TgC}^{-1}\right)$ & References \\
\hline Bohai Sea & 2.84 & Song (2004) \\
Yellow Sea & 27.38 & Fang et al. (1996) \\
& 8.96 & Song (2004) \\
& $6-12$ & Song (2004) \\
East China Sea & 1.2 & Fang et al. (1996) \\
& 4.3 & Hu and Yang (2001) \\
& 1.88 & Song (2004) \\
& 30 & Tsunogai et al. (1999) \\
& $13-30$ & \\
South China Sea & 16.65 & Fang et al. (1996) \\
& 7.69 & Han et al. (1997) \\
\end{tabular}

extensive phytoplankton photosynthesis that takes place in surface sea water during spring and early summer, transforming $\mathrm{CO}_{2}$ into organic $\mathrm{C}$ and thereby greatly reducing $\mathrm{CO}_{2}$ partial pressure in sea water for increasing the absorption of atmospheric $\mathrm{CO}_{2}$.

In present study, our result showed that the external $\mathrm{N}$ and $\mathrm{P}$ input significantly impacted on the $\mathrm{C}$ sink in China Seas. The ratio of $\mathrm{C}$ change caused by $\mathrm{N}$ and $\mathrm{P}$ input to total C sink for the Bohai Sea, the Yellow Sea, the East China Sea, and the South China Sea were 0.46, 0.45, 0.11, and 0.59 , respectively, which indicated the effect of $\mathrm{N}$ and $\mathrm{P}$ input on $\mathrm{C}$ cycle in China seas was enormous. Eutrophication has such deleterious effects on near-shore industries, residents, and ecologies that research on nutrient input, and the offshore DIC system is of the utmost importance for economic and environmental reasons. Humans are discharging more and more $\mathrm{N}$ and $\mathrm{P}$ into coastal waters, resulting in the fluxes of $\mathrm{N}$ and $\mathrm{P}$ that far exceed their natural production rate (Galloway and Cowling 2002; Foley et al. 2005). Excess nutrient loading is fast becoming a crucial environmental problem for coastal areas because it has such detrimental effects on environments. The excess nutrients promote eutrophication: bloom (the proliferation of fast-growing surface species, including phytoplankton, epiphytes, and opportunistic macro-algae Duarte 1995), hypoxia, and disturbance of the whole coastal and marine ecosystem. As Fig. 2 shows, although the Chinese government and its environmental protection 


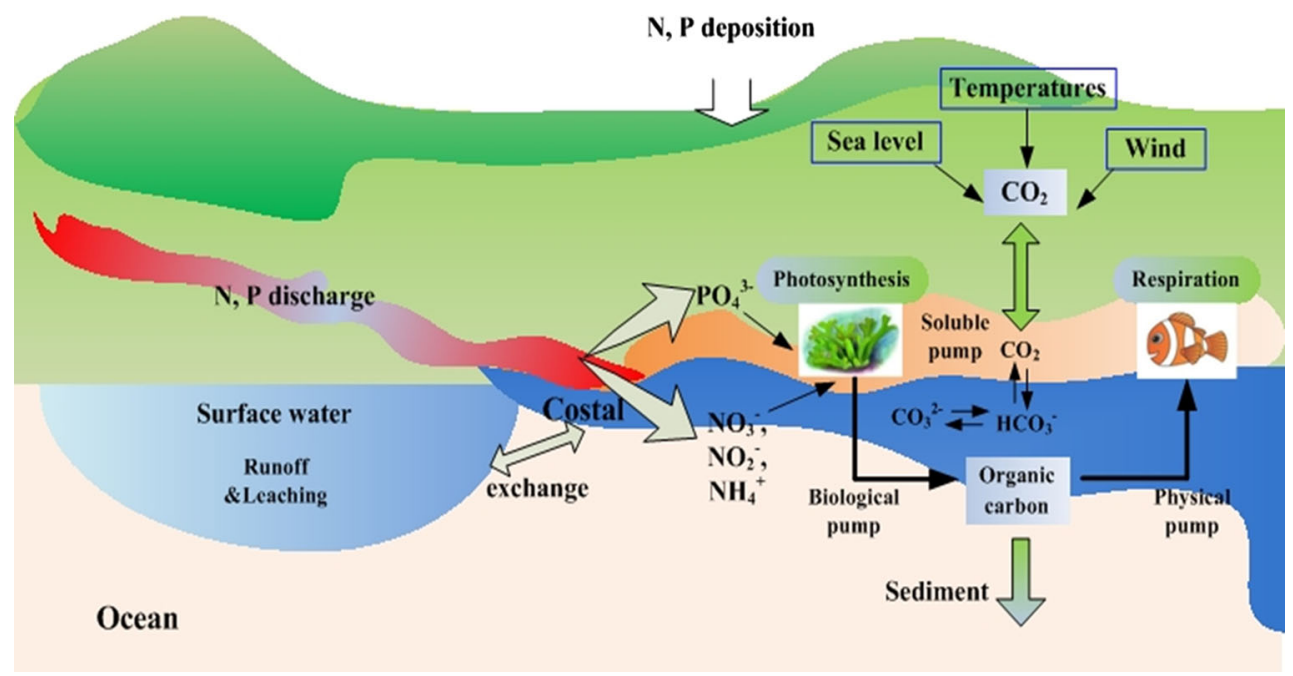

Fig. 7 Effect of $\mathrm{N}$ and $\mathrm{P}$ input on oceanic $\mathrm{C}$ cycle. Atmospheric $\mathrm{CO}_{2}$ dissolved into in sea water in the forms of $\mathrm{CO}_{3}{ }^{2-}$ and $\mathrm{HCO}_{3}{ }^{-}$is called as soluble pump effect. The $\mathrm{CO}_{2}$ that enters into oceanic ecosystem is constantly transformed into organic $\mathrm{C}$ and biological carbonate through photosynthesis, and then further transferred from the ocean surface to the deep ocean, which of the process is called as biological pump effect. Soluble and biological pump can enhance the $\mathrm{CO}_{2}$ absorption by ocean surface, impact on $\mathrm{CO}_{2}$ dissolved, and $\mathrm{C}$

agencies try to control $\mathrm{N}$ and $\mathrm{P}$ discharges from industry and residences, the $\mathrm{N}$ and $\mathrm{P}$ loading is still at an unacceptably high level. As long as China continues extensive economic development mode, it will be difficult to reach a satisfactory level of discharge.

Impact of nutrient input on the ocean $\mathrm{C}$ cycle

Oceanic $\mathrm{C}$ fluxes were believed to be dominated by microbial activity largely because bacteria and microalgae were the dominant source of primary production and respiration in the world's ocean (Duarte and Cebrian 1996; del Giorgio and Duarte 2002). Under current conditions, the oceans can absorb approximately $20-33 \%$ of the anthropogenic $\mathrm{CO}_{2}$ emitted from fossil fuels and industrial processes (Baliño et al. 2001). However, the exchange of $\mathrm{CO}_{2}$ that takes place in the air-sea interface, being regulated by the interplay between physical and biological processes, is not evenly distributed in space and time (Fig. 7).

As Fig. 7 shows, in the course of the primary production process, phytoplankton needs to absorb nutrients, such as nitrate and phosphate, from sea water. This leads to an increase in the alkalinity of surface waters, which reduces their $\mathrm{pCO}_{2}$. These two processes promote the increase of $\mathrm{pCO}_{2}$ on both of sea and air interface. This increase then strengthens the diffusion of atmospheric $\mathrm{CO}_{2}$ into the sea water and enhances $\mathrm{CO}_{2}$ sequestration by the sea. Bakker et al. (1999) also have reported that photosynthetic uptake of $\mathrm{CO}_{2}$ can lower DIC and $\mathrm{pCO}_{2}$. However, it must be transferred to the deep ocean. Ocean organisms' respiration mainly happens beneath the ocean mixed layer. The $\mathrm{CO}_{2}$ gas produced by ocean organisms' respiration and its effect on decomposition of organic $\mathrm{C}$ would increase sea water $\mathrm{CO}_{2}$ pressure increase and then result in the release of $\mathrm{CO}_{2}$ into the atmosphere, which of the process is called as physical pump (Frankignoulle et al. 1998; Bakker et al. 1999; Díaz and Rosenberg 2008; Jiao et al. 2010)

noted that the growth in the $\mathrm{C}$ content of sea water cannot increase unboundedly. If the increase in nutrients is greater than the capacity of the system to absorb the increased phytoplankton production, negative consequences follow. Algal blooms may result in increased sedimentation of organic matter on the seabed and subsequent oxygen depletion when they decompose (Glibert et al. 2005). Marine organisms begin to die as dissolved oxygen decreases to a critical level (Díaz and Rosenberg 2008).

In the present study, increased $\mathrm{N}$ and $\mathrm{P}$ input had markedly changed air-sea $\mathrm{CO}_{2}$ fluxes and $\mathrm{C}$ cycle in the coastal zone. This can be explained in part by purely chemical processes: nutrient input leads to the changes in the oceanic $\mathrm{C}$ circulation, which change sea water $\mathrm{pH}$ and air-sea $\mathrm{CO}_{2}$ fluxes, and then impacts on the $\mathrm{C}$ system. The biogeochemical changes due to eutrophication of sea water also stimulate ocean primary production and organic matter export (Invers et al. 2004). Phytoplankton in the euphotic zone takes up $\mathrm{CO}_{2}$ through photosynthesis, converting it to organic $\mathrm{C}$. The conversion of inorganic nutrient ions into primary productivity is expressed by the following reaction Eq. (9):

$$
\begin{gathered}
106 \mathrm{CO}_{2}+16 \mathrm{NO}_{3}^{-}+\mathrm{HPO}_{4}^{2-}+122 \mathrm{H}_{2} \mathrm{O} \\
\rightarrow\left(\mathrm{CH}_{2} \mathrm{O}\right)_{106}\left(\mathrm{NH}_{3}\right)_{16} \mathrm{H}_{3} \mathrm{PO}_{4}+138 \mathrm{O}_{2}
\end{gathered}
$$

Biological growth and decay both involve $\mathrm{CO}_{2}$. Biological uptake of $\mathrm{CO}_{2}$ and organic growth is accompanied by the consumption of nutrients; oxidation of organic detritus is normally accompanied by the release of nutrients 
and the production of $\mathrm{CO}_{2}$. This biological cycle is one of the main reasons to explain why increased nutrient input drives changes in the DIC system. Phytoplankton take up $\mathrm{CO}_{2}$ from sea water in the course of photosynthesis, so inorganic $\mathrm{C}$ thus becomes organic $\mathrm{C}$ and biologically available. When the phytoplankton is consumed by other marine flora and fauna, their organic $\mathrm{C}$ enters the food chain as particulate organic $\mathrm{C}$. If the phytoplankton die and sink to the sea floor, or the species that have fed upon them do so, the particulate organic $\mathrm{C}$ thus deposited may be decomposed and transformed into dissolved organic $\mathrm{C}$ by fungi or bacteria, or simply buried in sediment. This process affects other elements as well. Ocean thermohaline circulation and sedimentation of particulate matter would transport $\mathrm{C}$ from the ocean surface to the deep ocean, and finally, $\mathrm{C}$ is buried in the sediments, all of which form the main pathway for the ocean C cycle (IPCC 2005).

The elevated and well-balanced nutrient input can stimulate primary production and increase the $\mathrm{CO}_{2}$ uptake capacity of the sea; low or unbalanced nutrient inputs can limit coastal primary production, so the sea would act as the source for atmospheric $\mathrm{CO}_{2}$. Kevin (2005) has reported that deficiency or excess of $\mathrm{N}$ would both inhibit photosynthesis and prevent absorption of $\mathrm{C}$ in the DIC system. Ferial et al. (2001) have suggested that the biological drawdown of DIC and nutrients showed fixed ratios. Doney et al. (2007) have also reported that increased primary production stimulated by nitrogen lowers surface DIC, with a $\mathrm{C} / \mathrm{N}$ ratio of 6.6 (Eqs. 10, 11)

$$
\begin{aligned}
& 106 \mathrm{CO}_{2}+16 \mathrm{NO}_{3}^{-}+138 \mathrm{H}_{2} \mathrm{O} \\
& \rightarrow \text { organics }+16 \mathrm{OH}^{-}+138 \mathrm{O}_{2} \\
& 106 \mathrm{CO}_{2}+16 \mathrm{NH}_{4}^{+}+106 \mathrm{H}_{2} \mathrm{O} \\
& \rightarrow \text { organics }+16 \mathrm{OH}^{-}+106 \mathrm{O}_{2} .
\end{aligned}
$$

The importance of nutrient and phytoplankton growth limitation on air-sea $\mathrm{CO}_{2}$ flux in coastal area was also pointed by Cunha et al. (2007). Mackenzie et al. (2004) pointed out that both increased anthropogenic $\mathrm{CO}_{2}$ emissions and increasing nutrient inputs were the key players in the reversal of the air-sea $\mathrm{CO}_{2}$ flux in the global coastal zone. Our research also showed that nutrient inputs were the main drivers of the long-term air-sea $\mathrm{CO}_{2}$ sink. This study demonstrated that the calculated inter-annual variability of air-sea $\mathrm{CO}_{2}$ fluxes, and sink was related to the changes in $\mathrm{C}$ cycling driven by variations in nutrient loads. The increase in organic $\mathrm{C}$ input would stimulate heterotrophic activities and the emission of $\mathrm{CO}_{2}$, but this effect was counteracted by primary production stimulated by the concomitant increase of nutrient input (Gypens et al. 2009). Hence, it is clear that continued increase in nutrient inputs does not translate to a limitless increase in marine $\mathrm{CO}_{2}$ sinks.
Implications for future research

Like most of the world's oceans, the strength of the biological pump in the China seas is controlled by the availability of essential plant macronutrients, such as nitrate, phosphate, and silicate. The availability of nitrate or silicate can be altered if climate changes affect patterns of oceanic circulation, i.e. changes in upwelling of such macronutrients that are essential for the growth of phytoplankton, the engine that drives the biological pump (Smith et al. 1999; Xu et al. 2001; Carstensen et al. 2011). Moreover, climate change and episodic events can change the structure of ocean ecosystems and thus influence the efficiency and magnitude of the biological pump (Baliño et al. 2001; Larssen et al. 2011).

Our study suggests that changes in coastal waters could have global effects. The effect of nutrient inputs on oceanic $\mathrm{C}$ sink is enormous; the excess nutrients would impact on the $\mathrm{C}$ biogeochemistry cycle and the oceanic DIC system. Air-sea $\mathrm{CO}_{2}$ fluxes are driven both by climate change and human activity. Climate change will strengthen the average global temperature rises, which significantly impact on sea levels, sea water temperatures, enhanced hydrological cycles, and shifts in wind patterns, resulting in changes of air-sea $\mathrm{CO}_{2}$ fluxes. According to Pipko et al. (2002) and Orgeta et al. (2004), the DIC system in sea water is mainly determined by $\mathrm{pH}$ values, salinity, and $\mathrm{pCO}_{2}$. Increasing temperatures due to climate change have the potential effect on temperature and salinity in sea water. For example, a $1{ }^{\circ} \mathrm{C}$ increase in temperature would lead to a 1-psu decline in salinity, which changes sea water density (Fonfonoff and Millard 1983). Increased temperatures may also change regional wind patterns, which may either aggravate or alleviate low oxygen conditions in coastal waters. The largest human activities lead to excess $\mathrm{N}$ and $\mathrm{P}$ (both point and non-point sources) discharge and atmospheric deposition into ocean, which can also alter $\mathrm{pH}$ values and reduce total alkalinity (Fig. 7).

From Fig. 7, we see that any effect that climate change has on the nature and intensity of ocean circulation could have a strong impact on atmospheric $\mathrm{CO}_{2}$. Moreover, ocean warming may reduce the strength of the thermohaline circulation overturning cell, having an indirect effect on the efficiency of both physical and biological pumps. This in turn would feed back into the climate, potentially accelerating the rate of change. Changes in ocean chemistry due to increasing $\mathrm{CO}_{2}$ in surface waters are also likely to alter the long-term capacity for $\mathrm{C}$ uptake and influence the functioning of marine ecosystems dominated by calcifying organisms. At present, many uncertainties remain when estimating $\mathrm{C}$ cycles in the China seas. This is largely related to a lack of oceanic knowledge and partially due to current limitations on monitoring methods and associative 
instrumentation. Moving into the future, research should be intensified in China in order to cope with climate change, especially research that focuses on the following: (1) $\mathrm{CO}_{2}$ sources, sinks, and distribution patterns in the air-sea interface; (2) regulation of marine biogeochemical processes on atmospheric $\mathrm{CO}_{2}$; (3) driving factors of atmospheric and hydrological mechanisms on critical processes of ocean C cycles; (4) atmospheric N deposition estimations and terrestrial input impacts on $\mathrm{C}$ cycle processes; and (5) sustainable development of coastal biological $\mathrm{C}$ fixation.

\section{Conclusion}

This study demonstrates that external nutrient input significantly facilitates biological uptake of DIC and promotes air-sea $\mathrm{CO}_{2}$ fluxes and sink in Chinese coastal ecosystem. Coastal water quality is currently declining, due to eutrophication, but it can serve as a sink for atmospheric $\mathrm{CO}_{2}$. The excess nutrient inputs may account for 11-59\% of the $\mathrm{C}$ in the China seas, so the water eutrophication would significantly affects oceanic $\mathrm{C}$ sequestration and water quality. The effects of $\mathrm{N}$ and $\mathrm{P}$ on the changes in DIC and $\mathrm{pCO}_{2}$ also demonstrate that physiological and biochemical processes of $\mathrm{C}, \mathrm{N}$, and $\mathrm{P}$ are interconnected. The $\mathrm{N}$ and $\mathrm{P}$ import process is likely to cause cascade responses affecting $\mathrm{C}$ biochemical mechanisms. However, that excess nutrient input into coastal waters would result in negative effects on DIC and air-sea $\mathrm{CO}_{2}$ fluxes if the increase in nutrients is above the capacity of the $\mathrm{C}$ system. We can only conclude that the link between nutrient input and oceanic C sequestration is complex in which we know little about the effects of human activities and global climate change on eutrophication and oceanic $\mathrm{C}$ cycles.

Acknowledgments This work was financially supported by National Nature Science Foundation of China (No. 31200404 and 31290223); and the Program for "Bingwei" Excellent Talents in Institute of Geographic Sciences and Natural Resources Research, CAS. The authors would also like to thank the anonymous reviewers for their helpful remarks.

\section{References}

Bakker DCE, de Baar HJW, de Jong E (1999) The dependence on temperature and salinity of dissolved inorganic carbon in East Atlantic surface waters. Mar Chem 65:263-280

Baliño BM, Fasham MJR, Bowles MC (2001) Ocean biogeochemistry and global change. The International Geosphere-Biosphere Programme: A Study of Global Change of the International Council for Science (ICSU), Stockholm, Sweden

Bouillon S, Borges AV, Castaneda-Moya E (2008) Mangrove production and carbon sinks: a revision of global budget estimates. Glob Biogeochem Cycles 22(2):GB2013
Carstensen J, Sánchez-Camacho M, Duarte CM, Krause-Jensen D, Marba N (2011) Connecting the dots: responses of coastal ecosystems to changing nutrient concentrations. Environ Sci Technol 45:9122-9132

Chen CTA, Liu KK, Macdonald R (2003) The role of the ocean carbon cycle in global change. In: Fasham MJR (ed) Ocean biogeochemistry, chapter 3 continental margin exchanges. Springer, Berlin

Cunha LC, Buitenhuis ET, Le Quéré C, Giraud X, Ludwig W (2007) Potential impact of changes in river nutrient supply on global ocean biogeochemistry. Glob Biogeochem Cycles 21:GB4007

del Giorgio PA, Duarte CM (2002) Respiration in the open ocean. Nature 420:379-384

Díaz RJ, Rosenberg R (2008) Spreading dead zones and consequences for marine ecosystems. Science 321:926-929

Doney SC, Mahowald N, Lima I, Feely RA, Mackenzie FT, Lamarque JF, Rasch PJ (2007) Impact of anthropogenic atmospheric nitrogen and sulfur deposition on ocean acidification and the inorganic carbon system. Proc Natl Acad Sci USA 104(37):14580-14585

Duarte CM (1995) Submerged aquatic vegetation in relation to different nutrient regimes. Ophelia 41:87-112

Duarte CM, Cebrian J (1996) The fate of marine autotrophic production. Limnol Oceanogr 41(8):1758-1766

Falkowski P, Scholes RJ, Boyle E, Canadell J, Canfield D, Elser J, Gruber N, Hibbard K, Högberg P, Linder S, Mackenzie FT, Moore B III, Pedersen T, Rosenthal Y, Smetacek V, Steffen W (2000) The global carbon cycle: a test of our knowledge of earth as a system. Science 290:291-296

Fang JY, Liu GH, Xu SL (1996) Carbon cycles of Chinese terrestrial ecosystems and their global significances. In: Wang GC, Wen YP (eds) Greenhouse gases and their emission monitoring and some relative processes. China Environmental Science Press, Beijing, pp 129-139

Ferial L, Diana PRP, Catherine J, Christian B, Bernard S, Annick M, Michel F, Alain P (2001) Dissolved inorganic carbon, alkalinity, nutrient and oxygen seasonal and interannual variations at the Antarctic Ocean JGOFS-KERFIX site. Deep Sea Res (I) 48:1581-1603

Foley JA, DeFries R, Asner GP, Barford C, Bonan G, Carpenter SR, Chapin FS, Coe MT, Daily GC, Gibbs HK, Helkowski JH, Holloway T, Howard EA, Kucharik CJ, Monfreda C, Patz JA, Prentice IC, Ramankutty N, Snyder PK (2005) Global consequences of land use. Science 309:570-574

Fonfonoff P, Millard RC (1983) Algorithms for computation of fundamental properties of seawater, UNESCO Technical Papers in Marine Sciences, pp 44-53

Frankignoulle M, Abril G, Borges A, Bourge I, Canon C, Delille B, Libert E, Théate JM (1998) Carbon dioxide emission from European estuaries. Science 282(16):434-436

Galloway JN, Cowling EB (2002) Reactive nitrogen and the world: two hundred years of change. Ambio 31:64-71

Gao Y, Zhu B, Wang T, Wang YF (2012) Seasonal change of nonpoint source pollution-induced bioavailable phosphorus loss: a case study of Southwestern China. J Hydrol 420-421:373-379

Gao Y, Zhu B, Yu GR, Chen WL, He NP, Wang T, Miao CY (2014a) Coupled effects of biogeochemical and hydrological processes on $\mathrm{C}, \mathrm{N}$, and $\mathrm{P}$ export during extreme rainfall events in a purple soil watershed in southwestern China. J Hydrol 511:692-702

Gao Y, Zhu B, He NP, Yu GR, Wang T, Chen WL, Tian J (2014b) Phosphorus and carbon competitive sorption-desorption and associated non-point loss respond to natural rainfall events. J Hydrol 517:447-457

Glibert PM, Seitzinger S, Heil CA, Burkholder JM, Parrow MW, Codispoti LA, Kelly V (2005) The role of eutrophication in the 
global proliferation of harmful algal blooms. Oceanography 18:198-209

Global Carbon Project (2010) http://lgmacweb.env.uea.ac.uk/lequere/ co2/carbon_budget.htm

González JM, Fernandez-Gomez B, Fendandez-Guerra A, GómezConsarnau L, Sánchez O, Coll-Lladó M, Del Campo J, Escudero L, Rodríguez-Martínez R, Alonso-Sáez L, Latasa M, Paulsen I, Nedashkovskaya O, Lekunberri I, Pinhassi J, Pedrós-Alió C (2008) Genome analysis of the proteorhodopsin-containing marine bacterium Polaribacter sp. MED152 (Flavobacteria). Proc Natl Acad Sci USA 105(25):8724-8729

Gypens N, Borges AV, Lancelot C (2009) Effect of eutrophication on air-sea $\mathrm{CO}_{2}$ fluxes in the coastal Southern North Sea: a model study of the past 50 years. Glob Change Biol 15:1040-1056

Han WY, Lin HY, Cai YY (1997) Air-sea $\mathrm{CO}_{2}$ flux in the South China Sea. Oceanography 19(1):50-54 (in Chinese)

Houghton RA (2007) Balancing the global carbon budget. Annu Rev Earth Planet Sci 35:313-347

$\mathrm{Hu}$ DX, Yang ZS (2001) The key processes of the air-sea $\mathrm{CO}_{2}$ flux in the East China Sea. Ocean Press, Beijing (in Chinese)

Huertas E, Montero O, Lubián LM (2000) Effects of dissolved inorganic carbon availability on growth, nutrient uptake and chlorophyll fluorescence of two species of marine microalgae. Aquac Eng 22:181-197

Invers O, Pérez M, Romero J (2002) Seasonal nitrogen speciation in temperate seagrass Posidonia oceanica (L.) Delile. J Exp Mar Biol Ecol 273:219-240

Invers O, Kraemer GP, Pérez M, Romero J (2004) Effects of nitrogen addition on nitrogen metabolism and carbon reserves in the temperate seagrass Posidonia oceanica. J Exp Mar Biol Ecol 303:97-114

IPCC (2005) Carbon dioxide capture and sealing. In: Metz B, Davidson O, de Coninck H, Loos M, Meyer L (eds) Cambridge University Press, UK, pp 431

Jiao NZ, Herndl GJ, Hansell DA, Benner R, Kattner G, Wilhelm SW, Kirchman DL, Weinbauer MG, Luo TW, Chen F, Azam F (2010) Microbial production of recalcitrant dissolved organic matter: long-term carbon storage in the global ocean. Nat Rev Microbiol 8(8):593-599

Kevin JF (2005) Modeling marine phytoplankton growth under eutrophic conditions. J Sea Res 54:92-103

Larssen T, Duan L, Mulder J (2011) Deposition and leaching of sulfur, nitrogen and calcium in four forested catchments in China: implications for acidification. Environ Sci Technol 45(4):1192-1198

Liss P, Merlivat L (1986) Air-sea exchange rates, introduction and synthesis. In: Buat-Ménard P (ed) The role of air-sea exchange in geochemical cycling. NATO/ASI Series. D. Reidel, Dordrecht, pp 113-127

Mackenzie FT, Lerman A, Andersson AJ (2004) Past and present of sediment and carbon biogeochemical cycling models. Biogeosciences $1: 11-32$

Orgeta T, Ponce R, Forja J, Gómez-Parra A (2004) Fluxes of dissolved inorganic carbon in three estuarine systems of the Cantabrian Sea (north of Spain). J Mar Syst 53:125-142

Pipko II, Semiletov IP, Tishchenko PY, Pugach SP, Christensen JP (2002) Carbonate chemistry dynamics in Bering Strait and the Chukchi Sea. Prog Oceanogr 55:77-94

Raven JA, Falkowski PG (1999) Oceanic sinks for atmospheric $\mathrm{CO}_{2}$. Plant Cell Environ 22:741-755

Siegenthaler U, Sarmiento JL (1993) Atmospheric carbon dioxide and the ocean. Nature 365:119-125

Smith VH, Tilman GD, Nekola JC (1999) Eutrophication: impacts of excess nutrient inputs on freshwater marine and terrestrial ecosystems. Environ Pollut 100:179-196

Song JM (2004) Chinese coastal biogeochemistry cycle. Shandong Science and Technology Press, Jinan (in Chinese)

Tsunogai S, Watanabe S, Sato T (1999) Is there a "continental shelf pump" for the absorption of atmospheric $\mathrm{CO}_{2}$ ? Tellus 51B:701-712

Wanninkhof RH (1992) Relationship between wind speed and gas exchange over the ocean. J Geophys Res C 97:7373-7382

Weiss RF (1974) Carbon dioxide in water and seawater: the solubility of a non-ideal gas. Mar Chem 2:203-205

Xu FL, Tao S, Dawson RW, Li PG, Cao J (2001) Lake ecosystem health assessment: indicators and methods. Water Res 35(13):3157-3167

Zeebe RE, Wolf-Gladrow D (2005) $\mathrm{CO}_{2}$ in seawater: equilibrium, kinetics, isotopes. Elsevier, Amsterdam

Zhang NX (2008) Influence of external source nitrogen and phosphate on inorganic carbon source/sink. Doctoral dissertation

Zhang NX, Song JM, He JP, Li XG, Yuan HM, Li N (2007) Influence of external source nutrient and phosphate on dissolved inorganic carbon system in seawater simulated experiment. Studia Marian Sinica 48:67-75

Zhang NX, Song JM, Cao CH, Ren RZ, Wu FC, Zhang SP, Sun X (2012) The influence of macronitrogen $\left(\mathrm{NO}_{3}{ }^{-}\right.$and $\left.\mathrm{NH}_{4}{ }^{+}\right)$ addition with Ulva pertusa on dissolved inorganic carbon system. Acta Oceanol Sin 31(1):73-82

Zhi YL, Jin XC, Zhong Y (2008) Photosynthetic bicarbonate utilization by the fresh-water, green microalgae Chlorella pyrenoidosa and Scenedesmus obliquus. Acta Scientiae Circumstantiae 28(8):1519-1525 (in Chinese) 